\title{
The Recent Decline in Agricultural Exports: Is the Exchange Rate the Culprit?
}

\author{
Dallas S. Batten and Michael T. Belongia
}

\begin{abstract}
A between 1973 and 1980, the volume of U.S. exports of agricultural products exhibited no growth in 1981 and declined at a 5.0 percent annual rate in 1982 and 1983 Many analysts blame these export declines on the appreciation of the U.S. dollar.
\end{abstract}

Chattin and Lee, for example, attribute at least half of the export decline in 1982 and 1983 to this cause:

"Over the last two years, the real value of the dollar has appreciated just over 25 percent lon a trade-weighted basis) for importers of U.S. corn and 16 percent for importers of U.S. wheat. Our analysts estimate that . the United States has lost up to $\$ 6$ billion in farm export sales due to the strong dollar ${ }^{n+1}$

Similarly, Schuh, using the nominal agricultural export and exchange rate data plotted in chart 1 , concludes that "the export boom of the 1970s is seen to be closely tied to the fall in the value of the dollar. The decline in our export performance is closely associated with the rise in the value of the dollar in the 1980s."'

Dallas $S$. Batten is a senior economist and Michael T. Belongia is an economist at the Federal Reserve Bank of St. Louis. Sarah R. Driver provided research assistance.

'Chattin and Lee (1983), p. 19.

2Schuh (1984), p. 244. Other papers drawing a similar causal relationship between exchange rates and agricultural exports include Chambers and Just (1982), Tweeten (1983) and Hathaway (1983).
The problem with these statements is that such simple analyses generally are inadequate in establishing a cause-and-effect relationship between exchange rates and agricultural exports. First, the comparison in chart 1 fails to distinguish nominal changes in exchange rates, which reflect changes in relative rates of inflation across countries, from real changes in exchange rates, which reflect structural changes. An analysis of the impact of exchange rates on trade must first separate these two types of exchange rate changes, because only changes in real magnitudes influence trade flows.

Second, a simple two-variable comparison will not correctly identify the relationship between exchange rate movements and exports because factors other than exchange rate fluctuations influence export flows. This being the case, the relevant procedure is to isolate the marginal impact of exchange rates on trade, holding constant the impact of the other forces that affect export flows.

The purpose of this article is to explain the fundamental differences between nominal and real changes in exchange rates and to show why only real changes in exchange rates influence trade flows. In addition, the effects of real changes in exchange rates on export volume during the 1982-83 decline are estimated by using a simple econometric model of the determinants of world trade. 


\section{THE SOURCES OF EXCHANGE RATE FLUCTUATIONS}

Analysts generally agree that observed changes in exclkange rates are either nominal or real in nature." Nominal changes occur when the rates of inflation differ among countues. For example, if the U.S, tate of inflation is consistenty below those of th trading partners, then the U.S. dollar should appreciate at rates roughly equal to the spread between inflation rates. Real changes, on the other hand, reflect changing relative prices tdue to diverging structural devel opments among countries that have different effects on the exchange rate than on the relative rates of domestic inflation. For example, some would angue that the discovery of North Sea oil in the United Kingdom induced a substifution of domestically produced for imported oil, thereby causing the British pound to rise in value independent of any differences in inflation rates.

\section{Money Growth and Nominal Exchange Rate Changes}

The rate of domestic inflation and, hence, nominal changes in the exchange rate are detemined jointly by the rate of domestic money growth relative to the growth of the amount of money that individuals, domestic and foreign, desire to hold. A country's money supply is determined primarily by its monetary authority; the demand for money fie., the sum total of individual desires to hold a portion of thein wealth in the form of money) is determined primarily by income, real interest rates, prices and price expectations in that country and abroad. The equilibriam rate of inflation is the one that maintains continuous equality between the aggregate supply of and demand for money. Any other inflation rate generates a "monetary disequilibrium," which molivates individuals to alter their spending rate in order to bring their money holdings nearer to the amount they desire to hold.

Changes in the rate of consumer spending affect the demand for both domestically produced goods and services and those produced abroad. Altered demands for foreign goods and services, in turn, produce changes in the U.S. demand for foreign currencies and, as a consequence, changes in the foreign exchange

\footnotetext{
${ }^{3}$ See, for example, Korteweg (1980) and Pigott (1981).

${ }^{4}$ For a more detailed discussion, see Batten and Ot (1983).

${ }^{5}$ For example, see Chystal (1984) and Korteweg.
}

value of the dollar, all other things equal. Thus, a monetary disequilibrium, through its impact on the rate of aggregate spending, simultaneously induces a change in the rate of domestic inflation and the foreign exchange rate.

In the long run, the change in the foreign exchange rate will offset exactly the change in the rate of domestic inflation, all other things equal. "Therefore, while domestic inflation changes the domestic prices of exportable goods, it also changes the number of domestic currency units that a unit of foreign currency can purchase in proportion to the difference between the foreign and domestic inflation rates. Consequently, changes in the rate of money growth should have no long-run effects on either the foreign currency price of U.S. exports or the competitive positions of U.S. exporters in foreign markets.

\section{Purchasing Power Parity}

This link between nominal changes in the exchange rate and relative rates of domestic inflation is summafized by the concept of purchasing power parity (PPP), which can be expressed as:

(1) $\Delta \mathrm{e}=\pi_{\mathrm{f}}-\pi_{\mathrm{s}, \mathrm{s}}$,

where $\% \Delta e$ is the rate of change of the foreign curtency price of a U.S, dollar, and $\pi_{t: 5}$ and $\pi_{\mathrm{F}}$ denote the mates of inflation in the United States and a foreign country, respectively" If, for example, the rate of infation in the United States falls relative to inflation rates abroad, the number of units of foreign currency per dollar will rise; that is, the dollar will appreciate. Under ppp, nominal changes in exchange rates will offset differences in comestic inflation rates across countries. Therefore, if PPP is maintained, the offsetling effects of foreign and domestic inflation rates do not permit a change in the value of the dollar - over the long run - to affect rade of any lype, including agricultural trade. Consequently, if the appreciation of the dollar has produced the recent decine in U.S. agricultural exponts, PPP must not have been maintained during this era of flexible exchange rates.

\section{Money Growth and Real Exchange Rate Changes: Deviations from $P P P$}

Real changes in exchange rates imply deviations from PPP. Even though real changes in the exchange

\footnotetext{
Equation 1 actually represents the concept of relative PPP, which states that changes in the exchange rate will exactly offset the inflation differental. See Frenkel (1981).
} 
Chart 1

\section{Nominal U.S. Agricultural Exports and Nominal Exchange Rate}

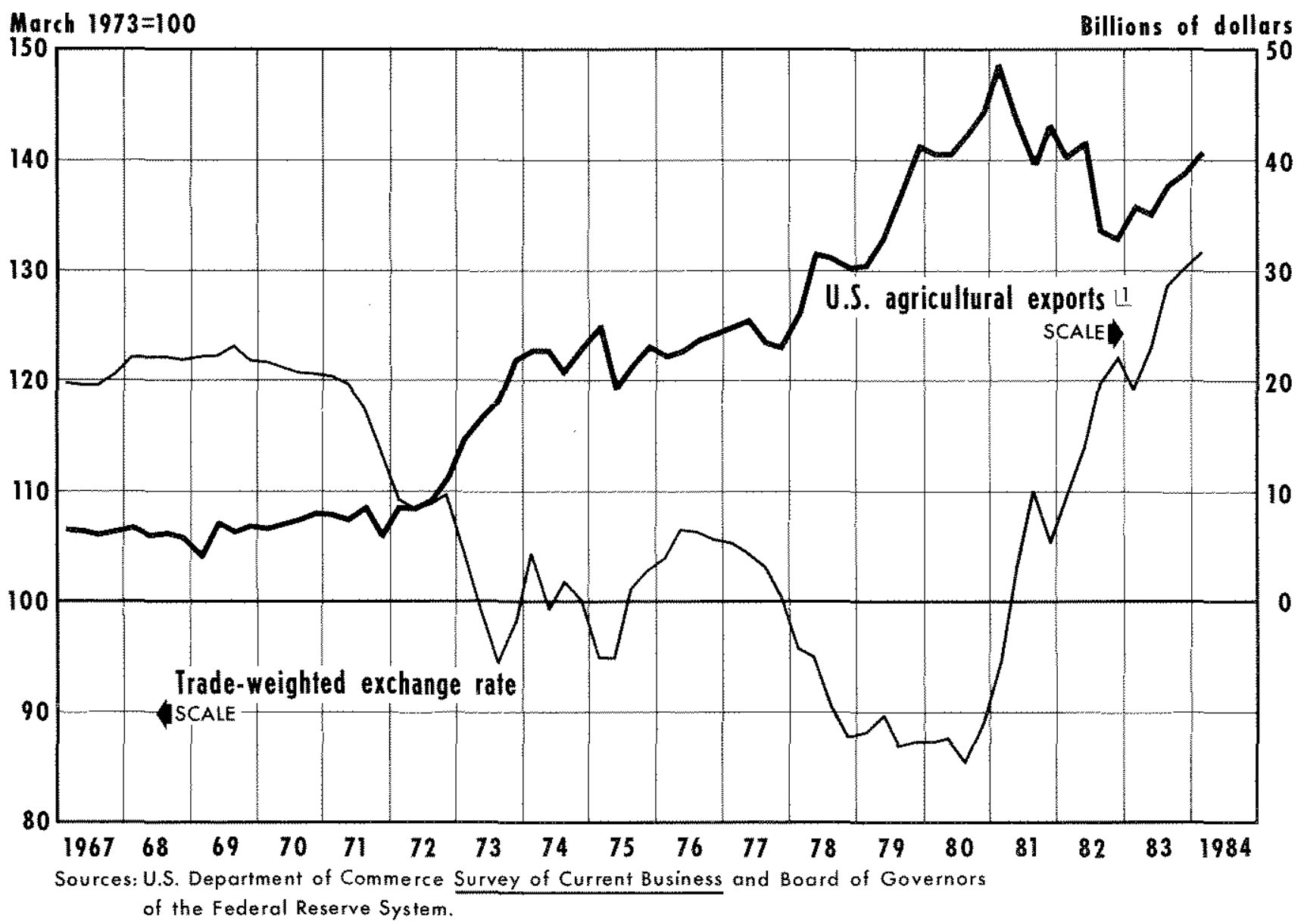

LI Seasonally adjusted annual rate.

rate typically are associated with structural differences in real economic performance across countries, the short-run adjustment to a monetary disequilibrium may generate temporary deviations from PPP.

If, for example, there is an unexpected decline in money growth, producers cannot discern immediately whether the associated decline in aggregate demand (spending) is permanent or merely temporary. Thus, they respond initially to a monetaryinduced reduction in demand by lowering their rate of production, which reduces the rate of real economic activity below its normal rate. Only when producers recognize that the decline in spending is a permanent adjustment to slower money growth will they sespond by reducing prices and retuming production to its normal rate. Hence, the impact of the monetary dis- equilibrium on output eventually vanishes, leaving only the rate of intlation permanently lowered. These long-run adjustments do not occur immediately, however, because there are lags in the transmission of information on the origin and magnitude of the shock to aggregate demand.

Unlike domestic commodity prices, exchange rates respond quickly to a monetary disequilibrium. The exchange rate is determined in highly organized, internationally integrated markets that quickly and efficiently assimilate new information. Consequently, it will change before commodity prices change sufficiently to regain the domestic monetary equilibrium.

${ }^{7}$ See Mussa $(1979,1982)$ and Dornbusch (1976). 
Chort 2

\section{Inflation Differential and Nominal Exchange Rate}

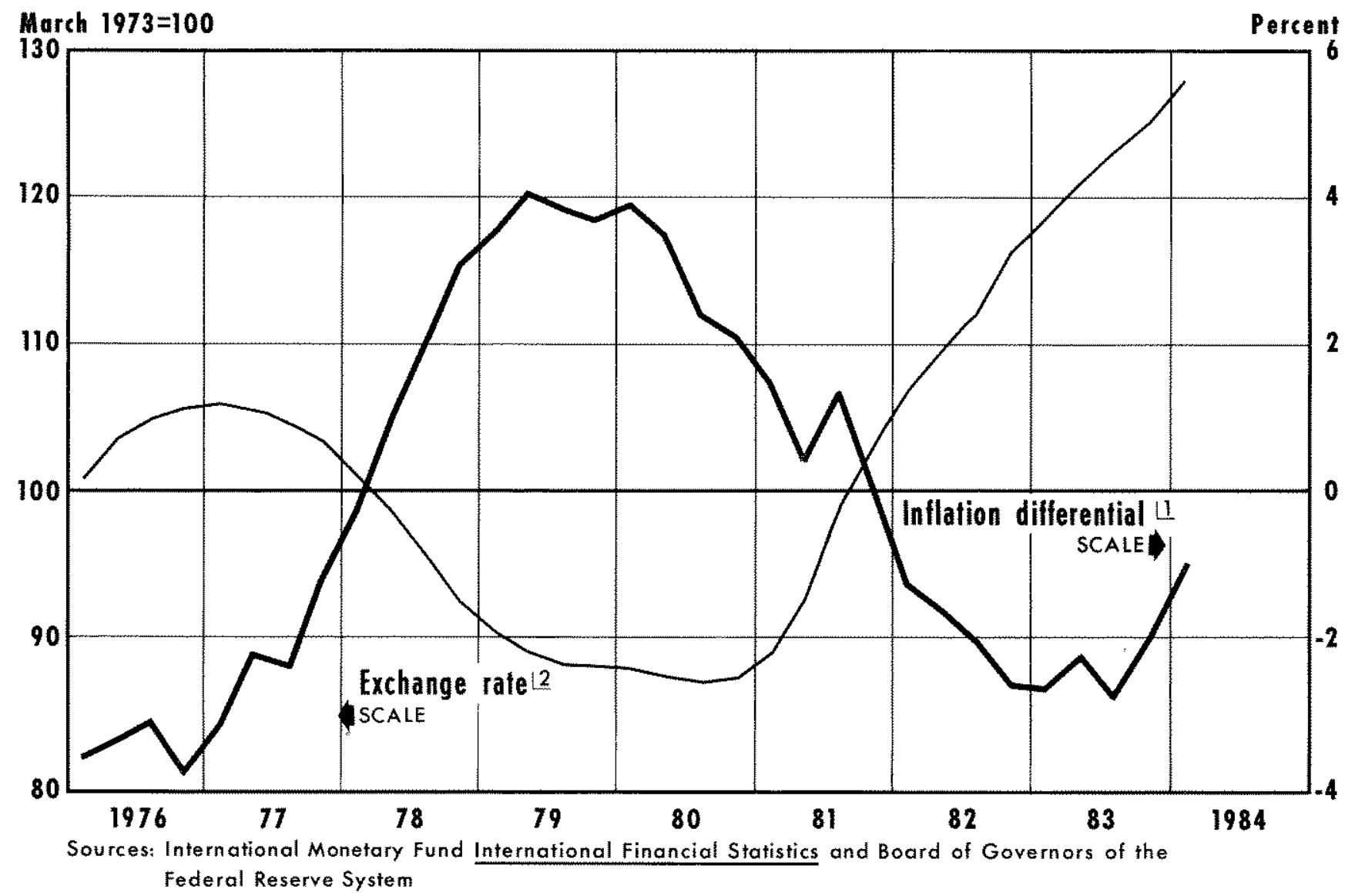

1 U.S. inflation minus trade-weighted foreign inflation

2 Four-quarter moving average of nominal trode-weighted exchange rate.

Between these two events, exporters will face a temporarily deteriorating competitive position in foreign markets. The exchange value of the dollar - and therefore, the prices paid by foreign importers of U.S. goods - will rise before the rate of domestic inflation and domestic commodity prices have declined by the full amount consistent with the reduction in the rate of money growth. This monetary-induced deviation from PPP, however, cannot persist for long.

\section{MONEY SHOCKS AND DEVIATIONS FROM PPP: THE EVIDENCE}

The general relationship between exchange rates and inflation differentials since 1976 is exhibited in chart 2. This chart shows the trade-weighted foreign currency value of the U.S. dollar and the difference between the U.S. rate of inflation (as measured by the CPI and the trade-weighted rate of inflation of the U.S.'s 10 major trading partners.

It is apparent from the chart that the foreign cur rency value of the dollar rises when the rate of domestic inflation falls relative to that of its major trading partners, and vice versa." This chart should not be

${ }^{9}$ For a description of the calculation of the trade-weighted exchange rate and the weights employed, see "Index of the Weighted. Average Exchange Value of the U.S. Dollar" (1978). The tradeweighted inflation differential is the difference between the rate of growth of the U.S. CPI and the rate of growth of the trade-weighted foreign $\mathrm{CPI}$ for the same countries and weights as used for the exchange rate.

${ }^{9}$ The simple correlation coefficient between the two series for the period $1 / 1976-1 / 1984$ is -0.766 ; the correlation between changes in the two series for the same period is -0.465 . Each is statistically significant at the 5 percent level. This analysis simply extends Batten and Luttren (1982) 


\section{Chart 3}

\section{Deviations from Purchasing Power Parity ${ }^{1}$}

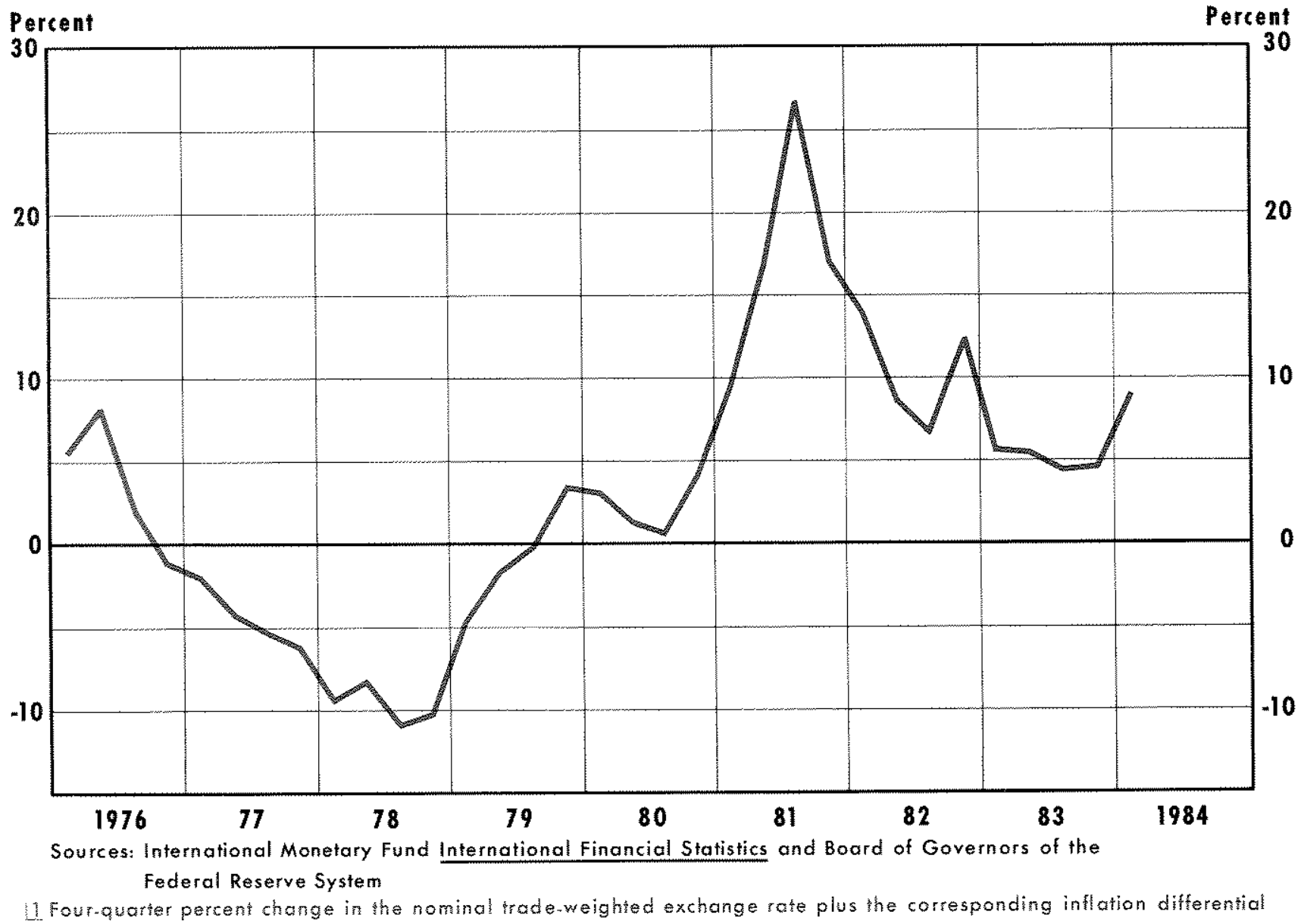

interpreted as proof of the existence of PPP; it does however, demonstrate that these series are inversely related, which is consistent with the notion that the rate of inflation and nominal changes in the exchange pate are jointly determined by excess money growth.

The issue of PPP is examined more closely in chart 3 Using the data in chart 2 to calculate values for equation 1 reveals that there have been significant and consistent positive deviations from ppP during the past four years. In other words, the rise in the value of the dollar has more than compensated for the decline in U.S. inflation relative to inflation in the rest of the world. ${ }^{10}$ Although this indicates the existence of devia-

10The use of a trade-weighted index of the foreign exchange value of the U.S. doliar may bias the calculation of PPP. Its use here is mainly for itustrative purposes. tions from PPP, there is no way to tell directly whether short-run adjustments to changes in money growth or changes in real phenomena are responsible. Atributing a cause-and-effect relationship between some event and exchange rates is difficult because it in volves a complete understanding of the dynamic process that characterizes the adjustment to a monetary shock. There are, however, several indirect routes to take.

\section{Previous Empirical Srudies}

One source of evidence is the existing literature on changes in money growth and exchange rates. Frankel 11979), for example, has analyzed the deutsche mark dollar relationship over the period from July 1974 to February 1978 . He found that with a once-and-formall 1 percent expansion of the U.S. money supply, the OM/\$ 


\section{Chart 4 \\ Deviations from Purchasing Power Parity and Monetary Shocks}

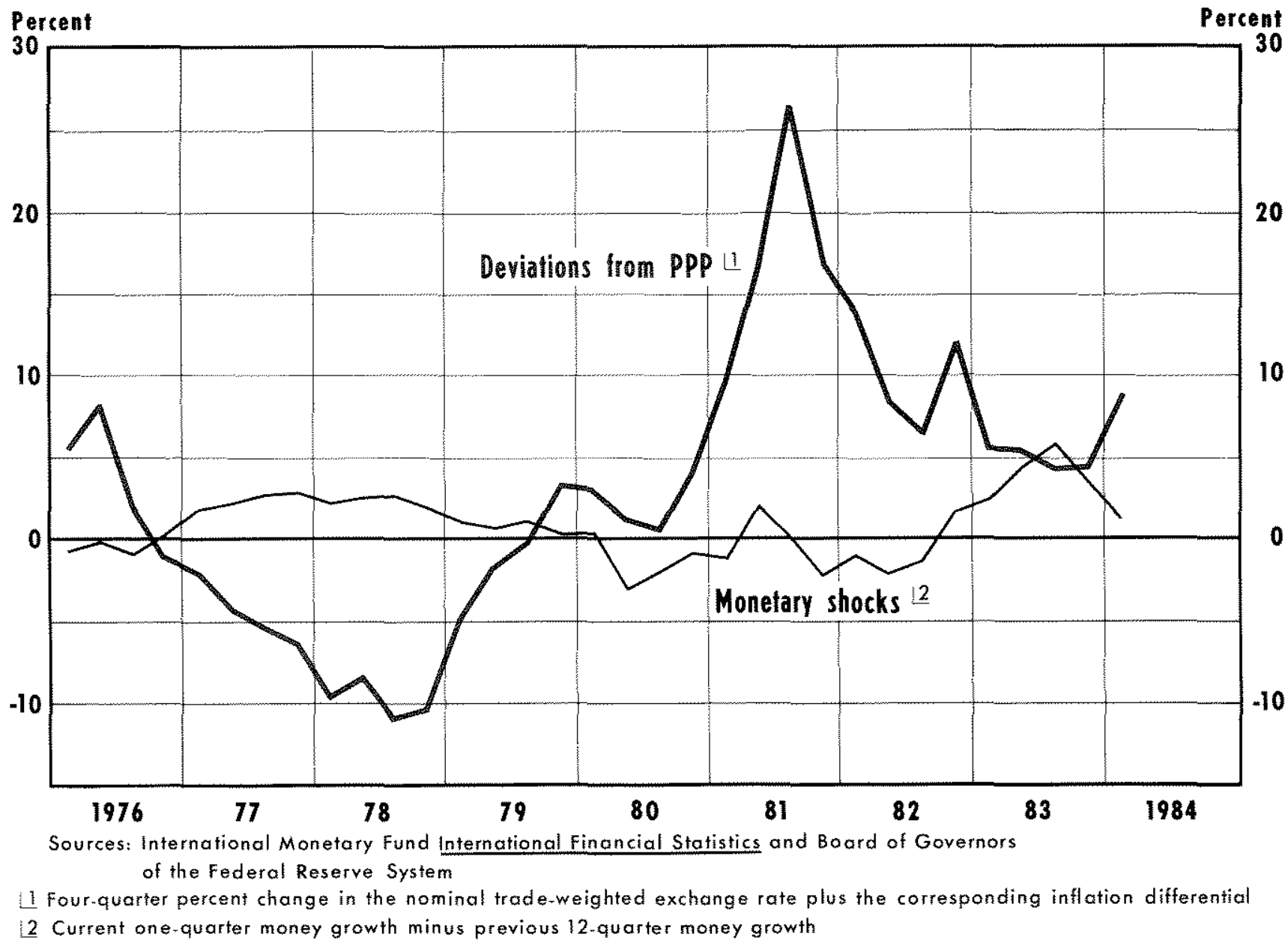

exchange rate overshot its PPP rate by 0.23 percent, all other things constant. After one vear, approximately 44 percent of this PPP deviation was eliminated.

Pigott also investigated the relative importance of real and nominal sources of monthly exchange rate changes. Using data from May 1973 to August 1980 for six currencies, he found that "real factors have represented a major source ... of exchange-rate fluctuations..." Moreover, monetary influences did not appear to have been substantially responsible for real changes in the exchange rate.

Finally, using Granger causality tests, Throop (1984) could find no statistically significant relationship between changes in the real exchange rate and current

1:Pigott (1981), p. 49 and past rates of money growth during the period from 1973 to 1980 . Therefore, unless the world has changed dramatically since 1980 , it appears unlikely that monetary shocks could have been the primary cause of the substantial and persistent devations from PPP that we have seen in the past four years. ${ }^{12}$

\section{A Comparison of the Data}

Another approach to assessing the link between money and PPP is simply to compare deviations from PPP with a measure of monetary shocks. Chart 4 does this using deviations from ppp (from chart 3) and monetary shocks measured as deviations of the quar-

\footnotetext{
12M1 growth does not Granger-cause changes in the real tradeweighted exchange rate even when the sample is extended to March 1984.
} 
Table 1

Changes In Bilateral Real Exchange Rates and Real Imports of U.S. Agricultural Products: Selected Coumtries

\begin{tabular}{|c|c|c|c|c|c|c|}
\hline \multirow[b]{2}{*}{ Cortfy } & \multicolumn{2}{|c|}{1934} & \multicolumn{2}{|c|}{1982} & \multicolumn{2}{|c|}{1983} \\
\hline & Exefaruge hale & Irparss & Txchange hare & lapoors & Exchange tarle & mpois \\
\hline Earice & $21.3 \%$ & $356 \%$ & $\operatorname{ses} 5$ & $268 \%$ & 1236 & 10,480 \\
\hline 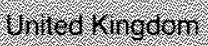 & 87 & 19.8 & 164 & 12 & 144 & 8.9 \\
\hline (entrint & 27. & 168 & 100 & 2,8 & $8 ?$ & -65 \\
\hline 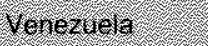 & 47 & 38 & 32 & 58 & -30 & 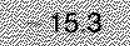 \\
\hline trat & 18.8 & 108 & 00 & 200 & 616 & 187 \\
\hline Wapan & 89 & 6. & $(150$ & $=32$ & 80 & 5.1 \\
\hline 14arosco & 263 & 160 & ts. & 157 & $1+146$ & 37 \\
\hline Sarat d riabra & 85 & 81.6 & 80 & 5.2 & 28 & 1 \\
\hline $14 \times 6.60$ & 125 & 25. & 48 & 86,6 & 402 & 210 \\
\hline Spering & 228 & 280 & 116 & 688 & 20.9 & 27 \\
\hline Canasa & tro & 5.1 & 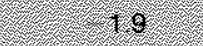 & 29 & 29 & 83 \\
\hline Nevertands & 265 & 18,3 & 94 & 156 & 74 & 123 \\
\hline
\end{tabular}

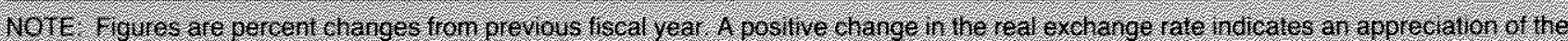
Collar against trat countys currency.

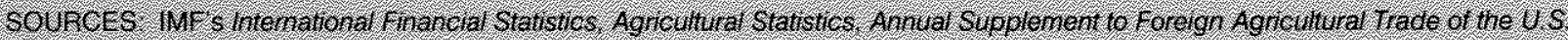

terly rate of U.S. M1 growth from the previous 12quarter moving average. If quarterly deviations of M1 growth from its frend growth accurately measure monetary shocks, and if monetary shocks were responsible for genenating deviations from PPP, a negative relationship should be revealed between the series in chart 4 . That is, faster than expected money growth should induce negative deviations from PPP, and vice versa. A comparison, however, reveals no statistically significant relationship between monetary shocks and deviations from PPP over the entire period."

\section{FACTOPS AFRECTINO AOTREUETURAL EXPORT DERAND}

The evidence presented above suggests that monetary policy has not been responsible for deviations from PPP during the 1980s. Thus, the real rise in the exchange rate came from other sources. Whatever the source, the real appreciation of the exchange sate over

\footnotetext{
${ }^{3}$ The simple correlation coefficient between the two sertes in chart 4 is -0.137 , which is not statistically different from zero at the 5 percent level. There is a subperiod, however, during which the hypothesized relationship is supported. In particular, the correlation between these sefies for the period l/1976-IV/1979 is -0.84. The correlation over the subsequent period (t/7980-//1984) is only $\sim 0.085$. Thus, monetary shocks are highly correlated with devia-
}

this period has been blamed as the primary cause of the recent decline in agricultural exports. The extent to which the real appreciation of the exchange rate has actually affected exports, however, remains to be investigated.

To do so requires identifying the marginal impact of real changes in the exchange rate on exports. A variety of factors other than exchange rates could be important determinants of the world's demand for U.S. agricultural exports. In fact, these factors could dominate the effect that exchange rates have had on the competitive trade position of U.S. agliculture.

\section{Agricultural Exports and Exchange Nates}

As an introduction to investigating the relationship between exchange rate changes and U.S. trade, consider how the volume of agricultural exports to specific countries has behaved since the dollar began to appreciate in real tems in 1981 . The countries listed in table 1 represent a broad cross-section of developed

tions from PPP during the former period, but not at all during the latter one.

Furthermore, when Granger causality tests were performed between monthly changes in the real trade-weighted exchange rate and monthly monetary shocks for the period March 1973-March 1984 , Granger-causality was statistically significant at the 5 percent level in only one of 144 different lag specifications investigated. 
and developing nations with a variety of capacites for domestic agricultural production. Moreover, because each nation's currency has changed in value relative to the dollar by a different amount, these data show individual cases for which a given movement in the real exchange rate has been associated with a particular change in a nation's imports of U.S. agricultural products. The nations listed replesent about half of U.S agricultural exports in the thee years shown.

The data in the table reveal no consistent relationship across countries between changes in the real value of their currencies relative to the dollar and changes in their leal imports of U.S. agricultural products. No county's trade pattem was completely consistent with an exchange rate explanation of trade flows: imports decreasing in years when the value of the dollar rose and increasing when the value of the dollar fell. Indeed, Morocco and Saudi Arabia generally increased their imports even though their currencies depreciated against the dollar in all three years. The import pattems of the other countries followed no consistent pattern over this interval. For example, the pound/dollar exchange rate increased between about 4 percent and 16 percent over the period, but changes in British imports nanged between 12.7 percent and -19.8 percent. Similarly, the Spanish peseta declined in both 1981 and 1982; imports in those 1 wo years, however, first fell by 25 percent, then rose by 64 percent.

\section{A Simple Model of U.S. Agricultural Exports}

Since the data in table 1 reveal no consistert relationship between real changes in the exchange rate and the volume of L.S. agricultumal exports, other factors must also be important deteminants of foreign demand for U.S. agriculumal products. To isolate the relative importance of these other influences, as well as to assess the marginal impact of exchange rate changes, a simple model of agricultural exports was constructed. ${ }^{14}$

This model focuses on the forces that affect the world demand for and the supply of U.S. agricultural exports. The world demand for US. agriculural exports was assumed to depend on just two factors the level of foreign real economic activity and the price of U.S. exports relative to those of other countries. The

\footnotetext{
${ }^{14}$ This model is fasthioned after those in Clark (1974). Goldstein and
} Khan (1978), Spitalter (1980) and Stevens, et al. (1984). higher the level of foreign real economic activity, other things equal, the larger would be foreign demand for U.S. agriculural exports. The higher the price of U.S. exports relative to those abroad, other things equal, the smaller would be the demand for U.S. agricultural exports.

On the other side of the market, the supply of U.S. agricultural exports was expressed as a function of the prices of U.S. agriculural exports relative to the prices of other goods and services produced in the United States and exogenous factors such as weather, embargoes, etc. Other things equal, the higher the price of U.S. agricutural exports relative to prices of other goods, the larger the production of U.S. agricultural products for export.

To generate an estimating equation for this model, a maket equilibrium was assumed and a reduced form obtained. Furthermore, since adjustment to price changes will not occur immediately, each relative price variable was specified as a distributed lag to capture the dynamics of this adjustment process. The real exchange rate was included to measure U.S, prices relative to those in the rest of the world lexpressed in dollars, net of changes in inflation differentials. Finally, a log-linear specification was employed, yielding the following equation estimated for the period $1 / 1971-1 / 1984$ :

$$
\begin{aligned}
& \text { (2) } \ln \mathrm{AGX}_{4}=0.73+1.32 \ln \text { (FGNP) } \\
& 0.54\} \quad(1093) \\
& -0.30 \stackrel{2}{\sum} b_{i} \ln (\mathrm{USAGP} / \mathrm{USCP})_{2-i} \\
& (5.43) i=1 \\
& -0.71 \stackrel{5}{\Sigma} c_{6} \ln (\mathrm{RTWER}) \\
& \{4.49\} j=1 \\
& \overline{\mathrm{B}}^{2}=0.94 \quad \mathrm{SE}=0.058 \quad \mathrm{DW}=1.51
\end{aligned}
$$

\footnotetext{
:5The lag lengths were chosen using procedures described in the appendix to Batten and Thornton (1984). A search for a distributed lag for foreign real income was also conducted, but none was found.
} 


$$
\ln =\text { the natural logarithm. }{ }^{\text {"i }}
$$

The absolute value of the t-statistic for testing the hypothesis that the estimated coefficient equals zero is reported in parentheses below each estimate. The equation fits the data well, explaining 94 percent of the variance of the natural logatithm of the volume of U.S. agricultural exports. ${ }^{T-}$

Since our objective is to assess the relative impacts of foreign economic activity and real exchange rates on export volume, the coefficients of FGN and RTWER are of particular interest. The log-linear specification generates estimated coefficients that are par tial elasticities. A partial elasticity measures the per. centage change of the dependent variable (AGX here) resulting from a 1 percent change in one of the independent (right-hand-side) variables, holding all other variables constant. For example, the estimated coefficient of RTWER measures the percentage change in the volume of U.S, agricultural exports resulting from a 1 percent change in the real exchange rate. In this case, a 1 percent increase in the real exchange rate leads to a 0.71 percent decline in the volume of U.S. agricultural exports. The significantly negative coefficient of RTWER suggests that increases in the value of the dollar indeed have contributed to the recent decline in U.S. agricultural exports. At the same time, however, the estimated equation contradicts the notion that exchange rate changes are the most impor tant determinant of U.S. agricultural exports.

This contradiction can be seen by calculating the standadized regression coefficients for the explanatory variables in the equation. The reported coefficients give no indication of the relative explanatory power of the independent variables, because these

16 Since weather is an important exogenous determinant of agricultural production, a dummy variable $(0,1)$ was included initially to reftect periods of below-rormal rainfal in the United States. The estimated coefficient of this variable is not statistically significant and, consequently, is not reported.

The real trade-weighted exchange rate, included to capture relative price changes, was calculated as:

RTWER = TWER $\times($ USCPITWFCPI),

where TWER = nominal trade-weighted exchange rate, and

TWFCPI $=$ trade-weighted loreign CPI (see lootnote 9 tor further details\}.

17The sum of the estmated coefficients of (USAGPUSCP) should be positive. The significantly negative coefficient may represent an example of the classical identification problem. For example, this may denote that the supply of agricultural exports may be shifting relatively more than the demand for agricutural exports during the period over which the equation is estimated. varables are expressed in diferent units. In contrast, the standardized regression coefficient is calculated from an equation in which the variables have been shandardzed (i.e. expressed in the same units). Consequently, a comparison of these coefficients indicates the relative importance of the independent variables in explaining the dependent variable.

In this case, the estimated standardized regression coefficht of foreign real income is 0.69 , while that of the real trade-weighted exchange rate is - 0.39. In other words, foreign demand for U.S. agricultural exports has been about 75 percen more sensitive to changes in foreign real economic activity (FGNP) than to changes in the real exchange value of the dollar. Based on these reduced-form coefficients, changes in foreign income have been primarty responsible for the changes in toreign demand for U.S. agricultural exports from $1 / 1971$ to $1 / 1984$.

\section{The 1982-83 Decline}

Though the data demonstrate that the level of foreign real economic activity has been a more imporIant deteminant of real U.S. agricultural exports than the real exchange rate since the early seventies, they shed no light on the question of why the volume of agnicultural exports has declined recently. Since the income eftect and the exchange rate effect have opposite signs, identifying whether the recent impact of changes in foreign real income is larger or smaller than that of changes in the real exchange rate would be straightforward if both world real income and the real exchange rate had risen during 1982 and 1983. During this period, however, the world experienced an economic recession as well as a real appreciation of the dollar. Consequenty, both effects resulted in lower exports of U.S. agricultural products.

To isolate these two effects, the following experiment was performed. First, the level of foreign real income was held at its W/1981 level. This date was chosen because it matks the beginning of the world recession.j Next, the model's predicted values for exports, holding foreign income constant, were compared with predicted export values, allowing foreign income to vary for the period $/ / 1982-\mathrm{V} / 1984$. The differ ence represents the marginal impact of changes in foreign real income on the predicted level of real agricultural exports. The simulation was repeated under conditions that hed the real exchange rate constant, then allowed it to vary as it did between $1 /$ 1982 and $\mathrm{l} / 1984$. 
The results are striking. From $1 / 1982$ to IV/1982, the marginal impact of the world recession was to reduce predicted U.S. agricultural exports by amost 2 per cent, while the marginal impact of the appreciation of the U.S. dollar was negligible. As the world economy began to recover in $1 / 1983$, the marginal impact of foreign income became positive, stimulating predicted U.S. agricultural exports by nearly 5 percent from $1 / 1983$ to $1 / 1984$. During the latter period, however, the continued appreciation of the dollar depressed predicted U.S agricultural exports by almost 7 percent, outweighing the positive impact of the world recovery. In sum, only during the past five quarters can the fall in U.S. agricultural exports be "blamed" on the appreciating dollar. Before that, the world reces" sion was the culprit.

\section{SUMNAFV AND CONCLUSTONS}

A number of economists have argued that increases in the foreign exchange value of the dollar have been responsible for recent declines in exports of U.S. agricultural commodities. These anguments, however, generally have been based on simple comparisons of exchange rates and exports. Moreover, they have not recognized essential distinctions between reat and nominal exchange rate changes.

The analysis presented in this article explained the fundamental differences between nominal and real movements in exchange rates and investigated the effects of variables other than the exchange rate on exports. Tabular data for 1981-83 indicated no consistent pattem between changes in the real value of the dollar and imports of U.S. agricultural commodities by foreign countries. More detalled empirical evidence on factors affecting the volume of U.S. agricultural exports showed that real exchange rates were related negatively to exports, but their impact was dominated by the level of real GNP in importing nations. Overall, the analysis suggests a weak link between U.S. money growth and real exchange rates and indicates that foreign income - not exchange rates - has been the primary deteminant of agricultural exports.

\section{PERERENCES}

Batten, Dallas S., and Clifton B. Luttrell. "Does Tight Monetary Policy Hurt U.S. Exports?" this Review (August/September 1982). pp. 24-27.

Batten, Dallas S., and Mack Ott. "Five Common Myths About Floating Exchange Rates," this Feview (November 1983), pp. 515.

Batten, Dallas S., and Daniel L. Thornton. "How Robust Are the
Policy Conctusions of the St. Louis Equation?: Some Further Evidence," this Review (June/July 1984), pp. 26-32.

Chambers, Robert G., and Richard E. Just. "An investigation of the Effect of Monetary Factors on Agriculture," Journal of Monetary Economics (March 1982), pp. 235-47.

Chattin, Barbara, and John E. Lee, Jr. "United States Agricultural Policy in a 'Managed Trade' World," in United States Farm Policy in a World Dimension, Special Report 305, Agricultural Experiment Station, University of Missouri-Columbia (November 1983), pp. 18-27.

Chrystal, K. Alec. "Dutch Disease or Monetarist Medicine?: The British Economy under Mrs. Thatchef," this Review (May 1984), pp. $27-37$.

Clark, Peter B. "The Effects of Recent Exchange Rate Changes on the U.S. Trade Balance," in Peter B. Clark, Dennis E. Logue and Richard James Sweeney, eds., The Eftects of Exchange Rate Adiustments, the Proceedings of a Conference sponsored by OASIS Research (Department of the Treasury, 1974), pp. $201-36$.

Dombusch, Rudiger. "Expectations and Exchange Rate Dynamics," Journal of Poitical Economy (December 1976), pp. $1161-$ 76.

Franket, Jeffrey A. "On the Mark: A Theory of Floating Exchange Rates Based on Real Interest Differentials;" American Economic Review (September 1979), pp. 610-22.

Frenkel, Jacob A. "The Collapse of Purchasing Power Parities During the 1970s," European Economic Review (May 1981), pp. 145-65.

Goldstein, Morris, and Mehsin S. Khan. "The Supply and Demand for Exports: A Simultaneous Approach," Review of Economics and Statistics (May 1978), pp. 275-86.

Hathaway, Dale E. "Agricultural Trade: 1984 and Beyond," in Outlook '84, Proceedings of the Agricultural Outlook Conference, U.S. Department of Agriculture, Washington, D.C. (November 1983)

:Index of the Weighted-Average Exchange Value of the U.S. Dollar: Revision," Federal Reserve Bulletin (August 1978), p. 700

Korteweg, Pieter. Exchange-Rate Policy, Monetary Policy, and Real Exchange-Aate Variability (Princeton University Press, 1980 ).

Mussa, Michael. "Empitical Regularities in the Behavior of Exchange Rates and Theories of the Foreign Exchange Market," in Karl Brunner and Allan H. Meltzer, eds., Policies for Employment, Prices, and Exchange Fates, Carnegie-Rochester Conference Series on Public Policy (1979), pp. 9-57.

"A Model of Exchange Rate Dynamics," Joumal of Political Economy (February 1982), pp. 74-104.

Pigott, Charles. "The Influence of Real Factors on Exchange Rates, "Federal Reserve Bank of San Francisco Economic Review (Fall 1981), pp. 37-54.

Schuh, G. Edward. "Future Directions for Food and Agricultural Trade Policy." American Joumal of Agricultural Economics (May 1984), pp. 242-47

Spitäller, Erich. "Short.Run Effects of Exchange Rate Changes on Terms of Trade and Trade Balance," IMF Staff Papers (June 1980), pp. $320-48$

Stevens, Guy V. G., et al. The U.S. Economy in an interdependent World: A Multicountry Model (Board of Governors of the Federal Reserve System, 1984).

Throop, Adrian W. "Anatomy of the 1981-83 Disinflation," Federal Reserve Bank of San Francisco Weekly Letter (March 23, 1984).

Tweeten, Luther. "Economic and Policy Outlook for U.S. Agriculture," in United States Farm Policy in a World Dimension, Special Report 305. Agriculturał Experiment Station, Universily of Missouri-Columbia (November 1983), pp. 13-17. 